\title{
EDITORIAL
}

\section{The Role of Biomarkers in Diagnosing the Early Stage of Endometriosis}

\author{
Wachyu Hadisaputra
}

Endometriosis is a disease that could lead to social problems in women. ${ }^{1}$ Delay in the diagnosis of endometriosis is not uncommon, even in developed countries. Previous studies in England and USA found that diagnostic delay could reach 8 and 12 years, respectively. ${ }^{2,3}$ These delays may occur at the individual level of women and medical level. At medical level, delay may be caused by the suppression of symptoms due to intermittent hormonal tręatment, failure of physicians to notice menstruation complaints and inadequate gynecologic examinations. ${ }^{2}$

Endometriosis is a chronic inflammatory condition associated with defects in immune system. It is clinically characterized by the presence of endometrial tissue outside the uterine cavity. ${ }^{4,5}$ Peritoneal fluid in endometriosis patient contained an increased level of active macrophages secreting various inflammatory products, including growth factors, cytokines and tumour markers. ${ }^{6}$ Increase in vascular epithelial growth factor (VEGF) was known as a mediator of angiogenesis, which enables endometrial cells to proliferate. Development of endometrial tissue was also caused by various cytokines such as interleukin-6 (IL-6) and tumour necrosis factor-alpha (TNF- $\alpha$ ). Furthermore, IL-6, Interleukin-8 (IL-8) and matrix metalloproteinase (MMP) were also associated with the implantation process of endometrial tissue. Interestingly, increased level of these cytokines was not only found in peritoneal fluid, but also in the serum of endometriosis patients. ${ }^{7-9}$

A lot of studies have described the relation between various biological markers and endometriosis diagnosis. However, IL-6, TNF- $\alpha$, MMP-2, and VEGF were found to have a higher correlation with the incidence of endometriosis compared to other biological markers. ${ }^{10}$ Thus, these markers can be a predictor for diagnosing the early stage of endometriosis if used along side with a combination of clinical symptoms, signs and other laboratory examination.

\section{References}

1. Siedentopf F, Tariverdian N, Rucke M, Kentenich H, Arck PC. Immune status, psychosocial distress and reduced quality of life in infertile patients with endometriosis. Am J Reprod Immunol 2008; 60: 449-61.

2. Ballard K, Lowton K, Wright J. What's the delay? A qualitative study of women's experiences of reaching a diagnosis of endometriosis. Fertil Steril 2006; 86: 1296-301.

3. Seear K. The etiquette of endometriosis: Stigmatisation, menstrual concealment and the diagnostic delay. Soc Sci Med 2009; 69: 1220-7.

4. Hadisaputra W. Endometriosis: Tujuan perangai imunopatobiologi sebagai modalitas baru untuk menegakkan diagnosis endometriosis tanpa visualisasi laparoskopi. Maj Obstet Ginekol Indones 2007; 31: 180-4.

5. Loh F-H, Bongso H, Fong C-Y, Koh D-R, Lee S-H, Zhao H-Q. Effects of peritoneal macrophages from women with endometriosis on endometrial cellular proliferation in an in vitro coculture model. Fertil Steril 1999; 72: 533-8.

6. Speroff L, Fritz AM. Clinical Gynecologic Endocrinology and Fertility. $8^{\text {th }}$ ed. Philadelphia: Lippincott Williams and Wilkins, 2011. p. 1221-48.

7. Harada T, Iwabe T, Terakawa N. Role of cytokines in endometriosis. Fertil Steril 2001; 76: 1-10.

8. Martinez S, Garrido N, Coperias J, Pardo F, Desco J, Vlasco JG, et al. Serum interleukin-6 levels are elevated in women with minimal mild endometriosis. Hum Reprod 2007; 22: 836-42.

9. Huang H-F, Hong L-H, Tan Y, Sheng J-Z. Matrix metalloproteinase 2 is associated with changes in steroid hormones in the sera and peritoneal fluid of patients with endometriosis. Fertil Steril 2004; 81: 1235-9.

10. Hadisaputra W, Prayudhana S. Serum biomarkers profiles of interleukin-6, tumor necrosis factor-alpha, matrix-metalloproteinase2, and vascular endothelial growth factor in endometriosis staging. Med J indones 2013; 22: 76-82. 